\title{
1969 ELECTION OF MEMBERS OF THE COUNCIL AND BOARD OF TRUSTEES
}

The tellers for the 1969 election, Jerry L. Kazdan and Norman Oler, have reported the election of the following members of the Council and Board of Trustees. The terms in each case begin on January 1, 1970.

President Elect, Nathan Jacobson

Vice President, Peter Lax, I. M. Singer

Associate Secretaries, Paul T. Bateman, Richard S. Pierce

Member of the Bulletin Editorial Committee, Murray H. Protter

Member of the Proceedings Editorial Committee, George B. Seligman, Joseph J. Rotman

Member of the Colloquium Editorial Committee, Saunders Mac Lane

Member of the Mathematical Reviews Editorial Committee, Oscar Goldman

Member of the Mathematical Surveys Editorial Committee, Bertram Yood

Member of the Transactions and Memoirs Editorial Committee, Steve Armentrout, S. Sternberg

Members-at-large of the Council, M. F. Atiyah, Philip Hartman, Michael Artin, Calvin C. Moore, C. C. Lin

Member of the Board of Trustees, George W. Mackey

Everett Pitcher, Secretary 